\title{
Have we succeeded in controlling anaemia in pregnancy - a prospective study at tertiary care center
}

\author{
Neena Gupta, Seema Diwedi, Neetu Singh, G.N. Diwedi, Fatima Usmani, Smriti Anand*
}

Department of Obstetrics and Gynecology, GSVM Medical College, Kanpur, U.P., India

Received: 28 April 2015

Accepted: 06 June 2015

\author{
*Correspondence: \\ Dr. Smriti Anand, \\ E-mail: smriti35@gmail.com
}

Copyright: $(\odot$ the author(s), publisher and licensee Medip Academy. This is an open-access article distributed under the terms of the Creative Commons Attribution Non-Commercial License, which permits unrestricted non-commercial use, distribution, and reproduction in any medium, provided the original work is properly cited.

\begin{abstract}
Background: WHO has accepted up to $11 \mathrm{gm} \%$ as the normal haemoglobin level in pregnancy. Therefore any haemoglobin level below $11 \mathrm{gm} \%$ in pregnancy should be considered as anaemia. Objective of current study was to determine prevalence of anaemia in pregnancy and various associated sociodemographic factors.

Method: A prospective study was carried out at GSVM Medical College, Kanpur during period Jan 2013 to August 2014. During this period all antenatal patients (4300) who came in outdoor and indoor were included in the study. Prevalence of anaemia among them and its associated sociodemographic factors were studied.

Result: In the current study we found the prevalence of anaemia in pregnant females was $92 \%$ of which most were moderately anemic (70\%) and belonged to age group 24-28 years of age, of higher parity, were of low socioeconomic status $(80 \%)$, illiterate and from rural areas $(54.4 \%)$. Anaemia was more prevalent in early age group because of early marriages \& in late age group because of multiple births

Conclusion: Despite of various National Nutritional Anaemia Prophylaxix programme in India, anaemia is still a significant challenge during pregnancy presenting mother and fetus at a greater risk of maternal and perinatal mortality and morbidity.
\end{abstract}

Keywords: Anaemic, Antenatal

\section{INTRODUCTION}

Anaemia is defined as reduction in circulating haemoglobin mass below the critical level. The normal haemoglobin concentration in the body is between 12-14 grams percent. WHO has accepted up to $11 \mathrm{gm} \%$ as the normal haemoglobin level in pregnancy. Therefore any haemoglobin level below $11 \mathrm{gm} \%$ in pregnancy should be considered as anaemia. ${ }^{20}$ The World Health Organization estimated that about $47.4 \%$ of world's population suffers from anaemia. Prevalence of anaemia in all the groups is higher in India as compared to other developing countries. Prevalence of anaemia in South Asian countries is among the highest in the world. WHO estimates that even among the South Asian countries, India has the highest prevalence of anaemia. What is even more important is the fact that about half of the global maternal deaths due to anaemia occur in South Asian countries; India contributes to about 80 per cent of the maternal deaths due to anaemia in South Asia. ${ }^{4}$

Studies carried out in India and elsewhere have shown that iron deficiency is the major cause of anaemia followed by folate deficiency. In recent years, the contribution of B12 deficiency has been highlighted. In India prevalence of anaemia is high because of

a) Low dietary intake, poor iron and folic acid intake

b) Poor bio availability of iron in Phytate and fibre rich Indian diet and

c) Chronic blood loss due to infection such as malaria and hookworm infestations.

Poor iron stores at birth, low iron content of breast milk and low dietary iron intake through infancy and childhood results in high prevalence of anaemia in childhood. 
Anaemia gets aggravated by increased requirements during adolescence and during pregnancy. Early marriage and adolescent pregnancy aggravate anaemia and result in poor iron stores in the offspring. It is obvious that there is an intergenerational self perpetuating vicious cycle of anaemia in Indian population. Assuming that the absorption of iron is $8 \%$ in pregnant women, their average dietary intake will meet only $30-45 \%$ of the requirement. The low dietary intake of iron, folic acid and food stuffs that promote iron absorption, couples with poor bioavailability of iron and lack of iron supplementation are the major factor responsible for very high prevalence of anaemia in pregnancy. ${ }^{7}$

\section{METHODS}

The present study was conducted on all anaemic antenatal cases irrespective of gestational age attending the hospital Upper India Sugar Exchange Maternity Hospital, GSVM medical college Kanpur.

Patient Profile: all antenatal patients (4300) were included in the study irrespective of gravida, parity and age.

Duration of Study: January 2013 to August 2014

Type of Study: Prospective Study.

\section{Inclusion criteria}

All anaemic antenatal cases irrespective of age, gravida, parity were included in the present prospective study and patient further divided into

\# mild anaemia - 9 -11 gm\%

\# moderate anaemia- 7 -9 gm\%

\# severe anaemia-4 -7 gm\%

\# very severe anaemia $-<4$ gm\% acc to $\mathrm{WHO}$

\section{Exclusion criteria}

All pregnant patients with medical disorder were excluded. After selection the patients were divided into two groups.

A. Control group- cases that were not anaemic in antenatal period.

B. Study group- this will be a prospective study in which all anaemic antenatal cases irrespective of gestational age enrolled and further classified as mild, moderate, severeand very severely anemic. In all patients (4300) included in the study haemoglobin level was done by Sahli's method and prevalence of anaemia was determined, the anaemic patients (3956) were further categorized in three groups according to WHO criteria mild, moderate, severe and very severe anaemic and in these patients epidemiological factors were studied. Standard of living index and Pareek classification was used to classify socio economic status.

\section{RESULTS}

Table 1: Prevalence of anaemia in pregnant females during study period (WHO criteria).

\begin{tabular}{|lll|}
\hline & $\begin{array}{l}\text { No of } \\
\text { patients }\end{array}$ & $\begin{array}{l}\% \text { of pts } \\
\text { prevalance }\end{array}$ \\
\hline $\begin{array}{l}\text { Total no of antenatal } \\
\text { patients attended hospital }\end{array}$ & 4300 & - \\
\hline $\begin{array}{l}\text { Total no of antenatal } \\
\text { patients who were anaemic }\end{array}$ & 3956 & $92.00 \%$ \\
\hline Mild anaemia (9-11 gm \%) & 791 & $20 \%$ \\
\hline $\begin{array}{l}\text { Moderate anaemia } \\
(7-9 \text { gm \%) }\end{array}$ & 2770 & $70 \%$ \\
\hline Severe anaemia(4-7 gm \%) & 277 & $7 \%$ \\
\hline $\begin{array}{l}\text { very severe anaemia } \\
(<4 \text { gm\%) }\end{array}$ & 118 & $3 \%$ \\
\hline
\end{tabular}

A total no of 4300 patients were studied the prevalence of anaemia was $92 \%$ and of which $70 \%$ were moderately anaemic and microcytic hypochromic.

Table 2: Distribution of anaemic patients in different age group.

\begin{tabular}{|llll|l|}
\hline $\begin{array}{l}\text { Age } \\
\text { Group }\end{array}$ & $\begin{array}{l}\text { Mild } \\
\text { anaemia } \\
\mathrm{Hb}- \\
(9-11 \\
\text { gm\%) }\end{array}$ & $\begin{array}{l}\text { Moderate } \\
\text { anaemiaHb } \\
(7-9 \text { gm\%) }\end{array}$ & $\begin{array}{l}\text { Severe } \\
\text { anaemia } \\
\mathrm{Hb} \\
(4-7 \\
\text { gm\%) }\end{array}$ & $\begin{array}{l}\text { Very } \\
\text { severe } \\
\text { anaemia } \\
(<4 \text { gm \%) }\end{array}$ \\
\hline $\begin{array}{l}18-23 \\
(1199)\end{array}$ & $\begin{array}{l}527 \\
(44 \%)\end{array}$ & $516(43 \%)$ & $108(9 \%)$ & $48(4 \%)$ \\
\hline $\begin{array}{l}24-28 \\
(1752)\end{array}$ & $\begin{array}{l}368 \\
(21 \%)\end{array}$ & $1016(58 \%)$ & $246(14 \%)$ & $122(7 \%)$ \\
\hline $\begin{array}{l}29-33 \\
(762)\end{array}$ & $\begin{array}{l}168 \\
(22 \%)\end{array}$ & $389(51 \%)$ & $136(18 \%)$ & $69(9 \%)$ \\
\hline $\begin{array}{l}>34 \\
(245)\end{array}$ & $\begin{array}{l}51 \\
(21 \%)\end{array}$ & $137(56 \%)$ & $30(12 \%)$ & $27(11 \%)$ \\
\hline Total & 1114 & 1908 & 256 & 266 \\
\hline
\end{tabular}

Most of these patients were in childbearing age 24-28 years and moderately anaemic. Severe anaemia was most prevalent in 29-33 year age group reflecting multiparity as a reason. Only $6.1 \%$ patients were in $>34$ year age group.

Table 3: Distribution of anaemic patients according to gravida / parity.

\begin{tabular}{|lllll|} 
Parameters & $\begin{array}{l}\text { Mild } \\
\text { anaemia }\end{array}$ & $\begin{array}{l}\text { Moderate } \\
\text { anaemia }\end{array}$ & $\begin{array}{l}\text { Severe } \\
\text { anaemia }\end{array}$ & $\begin{array}{l}\text { Very } \\
\text { severe } \\
\text { anaemia }\end{array}$ \\
\hline G1 & 165 & 583 & 30 & 14 \\
$(792)$ & $(20.9 \%)$ & $(21.05 \%)$ & $(10.90 \%)$ & $(12 \%)$ \\
\hline G2 & 172 & 673 & 63 & 29 \\
$(937)$ & $(21.8 \%)$ & $(24.29 \%)$ & $(22.72 \%)$ & $(25 \%)$ \\
\hline
\end{tabular}




\begin{tabular}{|lllll|}
\hline $\begin{array}{l}\mathrm{G} 3 \\
(1039)\end{array}$ & $\begin{array}{l}198 \\
(25.1 \%)\end{array}$ & $\begin{array}{l}729 \\
(26.31 \%)\end{array}$ & $\begin{array}{l}83 \\
(30 \%)\end{array}$ & $\begin{array}{l}29 \\
(25 \%)\end{array}$ \\
\hline$>\mathrm{G} 3$ & 256 & 785 & 101 & 46 \\
$(1188)$ & $(32.09 \%)$ & $(28.34 \%)$ & $(36.36 \%)$ & $(38 \%)$ \\
\hline $\begin{array}{l}\text { TOTAL } \\
(3956)\end{array}$ & 791 & 2770 & 277 & 118 \\
\hline
\end{tabular}

Chi square $=77.74$, 'p' value $<0.001$ inference $=$ highly significant

Severe $(36.36 \%)$ and very severe anaemia (38\%) was prevalent in patients with gravida>3 indicating a significant increase in number of anaemic patient as parity increased

Table 4: Distribution of anaemic patients as per habitat.

\begin{tabular}{|llll|l|}
$\begin{array}{l}\text { Total } \\
(3956)\end{array}$ & $\begin{array}{l}\text { Mild } \\
\text { anaemia } \\
(791)\end{array}$ & $\begin{array}{l}\text { Moderate } \\
\text { anaemia } \\
(2770)\end{array}$ & $\begin{array}{l}\text { Severe } \\
\text { anaemia } \\
(277)\end{array}$ & $\begin{array}{l}\text { Very } \\
\text { severe } \\
\text { anaemia } \\
(118)\end{array}$ \\
\hline $\begin{array}{l}\text { Rural } \\
(2155)\end{array}$ & $\begin{array}{l}(54 \%) \\
(54 \%)\end{array}$ & $\begin{array}{l}1468 \\
(53 \%)\end{array}$ & $\begin{array}{l}166 \\
(60 \%)\end{array}$ & $\begin{array}{l}94 \\
(80 \%)\end{array}$ \\
\hline $\begin{array}{l}\text { Urban } \\
(1801)\end{array}$ & 364 & 1302 & 111 & 24 \\
$(46 \%)$ & $(47 \%)$ & $(40 \%)$ & $(20 \%)$ \\
\hline
\end{tabular}

Chi square $=90.60$, 'p' value $<0.001$ inference $=$ highly significant

The above table shows that $54.4 \%$ population was from rural areas. Anaemia was more prevalent in rural population. $80 \%$ of severely anaemic patients were from rural areas which was statistically significant.

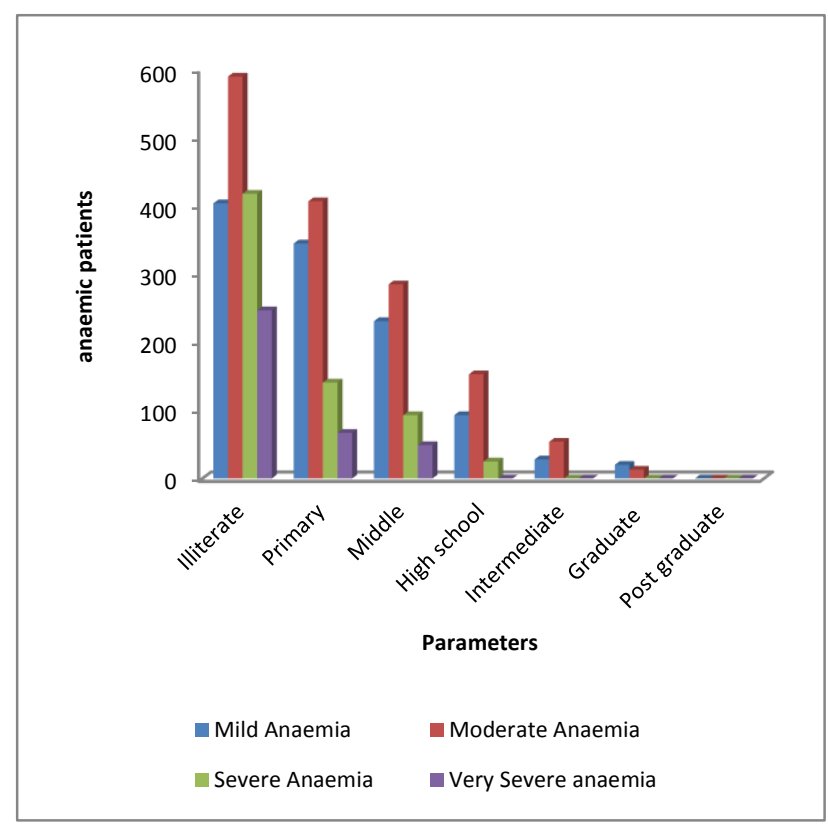

Graph 1: Distribution of anaemic patients according to their educational status.

There was a trend of lower incidence of anaemia with higher per capita income
Table 5: Distribution of anaemic Patients According to Socioeconomic Status.

\begin{tabular}{|c|c|c|c|c|}
\hline & $\begin{array}{l}\text { Mild } \\
\text { anaemia }\end{array}$ & $\begin{array}{l}\text { Moderate } \\
\text { anaemia }\end{array}$ & $\begin{array}{l}\text { Severe } \\
\text { anaemia }\end{array}$ & $\begin{array}{l}\text { Very } \\
\text { severe } \\
\text { anaemia }\end{array}$ \\
\hline $\begin{array}{l}\text { Lower } \\
\text { socio } \\
\text { economic } \\
\text { status } \\
(2353)\end{array}$ & $\begin{array}{l}426 \\
(53.9 \%)\end{array}$ & $\begin{array}{l}1672 \\
(60.3 \%)\end{array}$ & $\begin{array}{l}167 \\
(60 \%)\end{array}$ & $\begin{array}{l}88 \\
(75 \%)\end{array}$ \\
\hline $\begin{array}{l}\text { Middle } \\
\text { socio } \\
\text { economic } \\
\text { status } \\
(1144)\end{array}$ & $\begin{array}{l}292 \\
(37 \%)\end{array}$ & $\begin{array}{l}739 \\
(26.7 \%)\end{array}$ & $\begin{array}{l}90 \\
(32.7 \%)\end{array}$ & $\begin{array}{l}23 \\
(20 \%)\end{array}$ \\
\hline $\begin{array}{l}\text { Upper } \\
\text { socio } \\
\text { economic } \\
\text { status } \\
(459)\end{array}$ & $\begin{array}{l}73 \\
(9.05 \%)\end{array}$ & $\begin{array}{l}359 \\
(12.9 \%)\end{array}$ & $\begin{array}{l}20 \\
(7.2 \%)\end{array}$ & $\begin{array}{l}7 \\
(5 \%)\end{array}$ \\
\hline TOTAL & 791 & 2770 & 277 & 118 \\
\hline
\end{tabular}

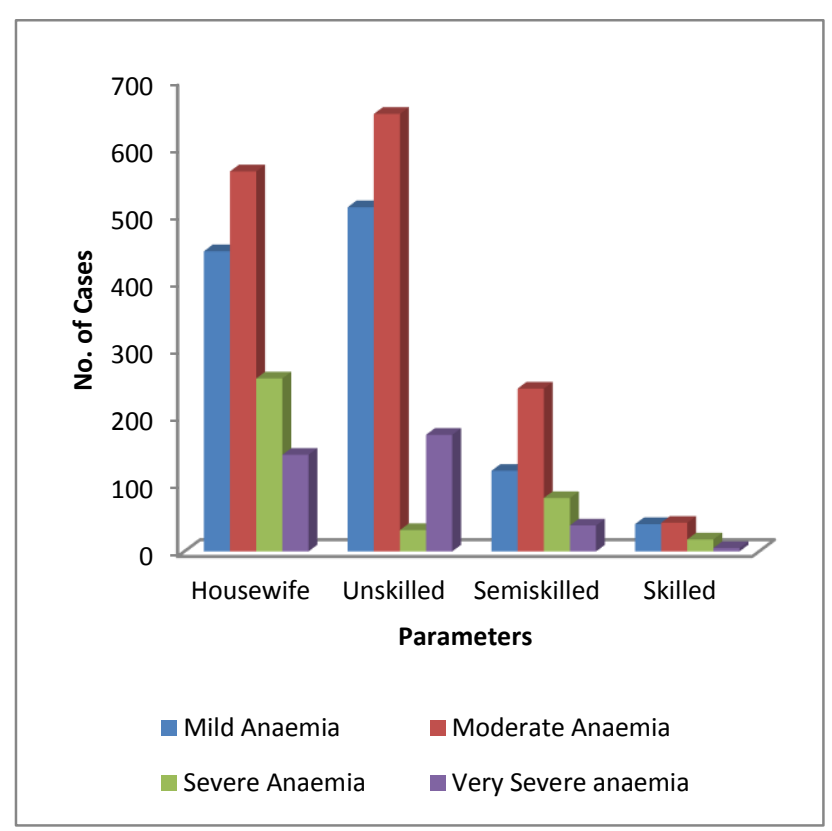

Graph 2: Distribution of anaemic patients according to occupation.

\section{DISSCUSSION}

In our study we found the prevalence of anaemia in pregnant females during our study period was $92 \%$ of which moderate were $70 \%$, mild $20 \%$, severe $7 \%$ \& very severe were $3 \%$ using WHO criteria as degree of anaemia which is in agreement with the study conducted by Vivek et al. 2012 studied prevalence of anaemia in pregnant women ${ }^{10}$. They also found a high prevalence of $82.9 \%$ of anaemia in pregnant women. Same prevalence is also supported by Lokare et al. 2012 who has found $87.2 \%$ of anaemia in their study. Various other studies have been done which have shown prevalence upto $91.2 \%$ of anaemia. $^{7}$ 
In our study we found that most of the anaemic patient belong to age group of 24-33 years of age. Anaemia is more prevalent in early age group because of early marriages $\&$ in late age group because of multiple births. Various other studies have shown same results. Gautam et al. (2002) in their study showed that maximum cases of anaemia belong to the age $<30$ years. ${ }^{4}$

In our study total no. of anaemia cases as well as total no. of moderate, severe \& very severe anaemia cases were more in rural population, $\mathrm{P}$ value here is also $<0.001$ which is highly significant showing significant differences among both the groups. This finding is supported by Rao, 1983 who surveyed that in rural India anaemia is much more widespread than urban area.

In present study, majority of anaemic patients were illiterate. Anaemia is much more prevelant in less educated people.

In our study distribution of cases according to socioeconomic status showed that majority of anaemic patients belonged to low socio-economic strata which again showed the high prevalence of anemia among the underprivileged sector of society, our study was in same finding with study done by Vivek et al. 2012. ${ }^{10}$

In our study we found that anaemia is much more prevalent in multipara \& grand multipara, patient who had inadequate dietary intake $\&$ most common cause of our anaemia in our study was found to be iron deficiency anaemia.

All these demographic observations of our study are well supported by survey conducted by WHO in developing countries \& by National Family Health Survey 3 (NFHS) (2005-2006) in India.

\section{CONCLUSION}

In conclusion, Government of India have started "National Nutritional Anaemia Prophylaxis Programme" since 1970.In accordance to it every pregnant women is getting 100 Iron Folic tablets but even after 45 years of launching anemia control programme in India it seems to have no noticeable effect. On improvement of prevalence of iron deficiency anemia and there is a great need for further health education promotional programme in this respect.

\section{ACKNOWLEDGEMENTS}

I wish to express my sincere gratitude towards my coauthors- Dr. Neena Gupta, Dr Seema Dwivedi, Dr N eetu singh Dr Fatima I thank Dr Kiran Pandey, the HOD for her support and encouragement. I wish to thank all my colleagues and students for their love and affection. Last but not the least, I wish to thank my patients for their belief in me and for their co-
Funding: No funding sources

Conflict of interest: None declared

Ethical approval: The study was approved by the

Institutional Ethics Committee

\section{REFRENCES}

1. Colomer $\mathbf{J}$, et al. Anaemia during pregnancy as a risk factor for infant iron deficiency: report from the Valencia Infant Anaemia Cohort (VIAC) study. Paediatr Perinat Epidemiol. 1990;4:196-204.

2. Vijaynath, Patil RS, Jitendra, Prevalence of anemia in pregnancy, 2008.

3. McLean E, Cogswell M, Egli I, Wojdyla D, De Benoist B. Worldwide prevalence of anaemia, WHO Vitamin and Mineral Nutrition Information System, 1993-2005. Public Health Nutrition. 2009;12(4):444-54.

4. Gautam VP, Bansal Y, Taneja DK, Renuka S. Prevalence of anaemia amongst pregnant women and its socio-demographic associates in rural area of Delhi. Indian J Community Med. 2002;27:157.

5. Human Development Report 2006. Washington, DC: World Bank; 2006.

6. Knottnerus JA, Delgado LR, Knipschild PG, Essed GG, Smits F. Haematologic parameters and pregnancy outcome. A prospective cohort study in the third trimester. J Clin Epidemiol. 1990;43:461-6.

7. Lokare PO, Karanjekar VD, Gattani PL, Kulkarni AP. A study of prevalence of anemia and socio demographic factors associated with anemia among pregnant women in Aurangabad city, India. Ann Nigerian Med. 2012;6:30-4.

8. Murphy JF, New combe RG, Coles EG, Pearson JF. Relation of Hemoglobin levels in First and Second Trimesters to Outcome of Pregnancy. Lancet. 1986;992-56.

9. Prevention and management of severe anemia in pregnancy. WHO, Geneva, 1993.

10. Viveki RG, et al. Al Ameen Charitable Fund Trust, Bangalore Prevalence of Anaemia and Its Epidemiological Determinants in Pregnant Women, 2012.

11. Thirukkanesh S, Zahara AM. Compliance to vitamin and mineral supplementation among pregnant women in urban and rural areas in Malaysia. Pakistan Journal of Nutrition. 2010;9(8):744-50.

12. Sharma A, Patnaik R, Garg S, Ramachandran P. Detection \& management of anaemia in pregnancy in an urban primary health care institution. Indian $\mathbf{J}$ Med Res. 2008;128:45-51.

13. Sight and Life, "Nutritional Anemia," SIGHT AND LIFE Press, 2007, http://www.sightandlife.org/ fileadmin/data/Books/ Nutritional anemia book.pdf.

14. Thangaleela T, Vijayalakshmi P. Impact of anaemia in pregnancy. Indian journal of nutrition and dietetics. 1994;31:9251-6.

15. The World Health Report. Reducing risks, promoting healthy life. World Health Organization. Geneva. 2002; 248-249. 
16. Trends in Maternal Mortality: 1990 to 2008 Estimates developed by WHO, UNICEF, UNFPA and The World Bank.

17. UNICEF, UNU, WHO, Iron Deficiency Anemia: Assessment, Prevention, United Nation, United Nations Millennium Declaration: Resolution Adopted By the Geneal Assembly, United Nation, Newyork, NY, USA, 2000.

18. Vijaynath, Jitendra, Ramesh $P$, Abhishek $P$. Prevalence of anemia in pregnancy. Indian Journal of Applied Basic Medical Sciences. 2010;12:23-35.

19. WHO. Haemoglobin Concentrations for the Diagnosis of Anaemia and Assessment of Severity,
Vitamin and Mineral Nutrition Information System, WHO, Geneva, Switzerland, 2011.

20. WHO, Maternal Health and Safe Motherhood Division of Family Health. (1991) The prevalence of nutritional anaemia in women. Geneva.

Cite this article as: Gupta N, Diwedi S, Singh N, Diwedi GN, Usmani F, Anand S. Have we succeeded in controlling anaemia in pregnancy - a prospective study at tertiary care center. Int J Reprod Contracept Obstet Gynecol 2015;4:995-9. 